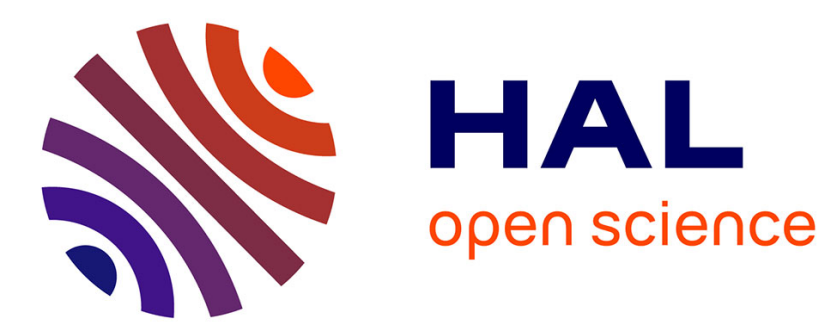

\title{
Patterns of lineage diversification in rabbitfishes
}

Philippe Borsa, Sarah Lemer, D. Aurelle

\section{To cite this version:}

Philippe Borsa, Sarah Lemer, D. Aurelle. Patterns of lineage diversification in rabbitfishes. Molecular Phylogenetics and Evolution, 2007, 44, pp.427-435. 10.1016/j.ympev.2007.01.015 . hal-00553682

\section{HAL Id: hal-00553682 \\ https://hal.science/hal-00553682}

Submitted on 8 Jan 2011

HAL is a multi-disciplinary open access archive for the deposit and dissemination of scientific research documents, whether they are published or not. The documents may come from teaching and research institutions in France or abroad, or from public or private research centers.
L'archive ouverte pluridisciplinaire HAL, est destinée au dépôt et à la diffusion de documents scientifiques de niveau recherche, publiés ou non, émanant des établissements d'enseignement et de recherche français ou étrangers, des laboratoires publics ou privés. 
To be cited as:

Borsa P., Lemer S., Aurelle D. 2007. - Patterns of lineage diversification in rabbitfishes. Molecular Phylogenetics and Evolution 44, 427-435.

\section{Patterns of lineage diversification in rabbitfishes}

Philippe Borsa ${ }^{a, *}$, Sarah Lemer ${ }^{a, b}$, Didier Aurelle ${ }^{b}$

a Institut de recherche pour le développement, UR 128, Nouméa, New Caledonia

b Dimar (UMR 6540 CNRS / Université de la Méditerranée), Station marine d'Endoume, rue de la Batterie des lions, Marseille, France

* Corresponding author. Fax: +687 264326.

E-mail address: Philippe.Borsa@noumea.ird.nc (P. Borsa) 
Abstract - Fishes of the tropical Indo-Pacific family Siganidae comprise 28 species, characterized by their body proportions and their colour patterns. A mitochondrial phylogeny of 20 Siganidae species was produced to infer their evolutionary history. Three distinct, major clades were found, that also correspond to the early radiation of the family into three major ecological types: fusiform species that also live in schools on the inshore reef flats (S. canaliculatus, S. fuscescens, S. luridus, $S$.

rivulatus, $S$. spinus, $S$. sutor); deep-bodied species including brightly coloured ones whose adults live in pairs on the reef front (S. corallinus, S. doliatus, S. puellus, S. punctatus, S. unimaculatus, S. virgatus, S. vulpinus), and species that live in small schools in mangroves, estuaries and estuarine lakes (S. guttatus, S. javus, S. lineatus, S. randalli, S. vermiculatus); and a third clade including a cosmopolitan species, $S$. argenteus, the only species of the family known to possess a pelagic, prejuvenile stage and $S$. woodlandi, a recently described species from New Caledonia and morphologically close to $S$. argenteus. The partition of the genus into two sub-genera, Lo (erected for $S$. unimaculatus, S. vulpinus and three related species possessing a tubular snout) and Siganus (all the other species), had no phylogenetic rationale. The present results indicate that the tubular snout, which apparently results from ecological specialization, is a recent acquisition within the deep-body clade. The Western Indian Ocean endemic S. sutor appeared as the sister-species of the Red Sea endemic S. rivulatus within a well-supported subclade that also included S. canaliculatus and S. fuscescens. S. spinus did not appear as sister-species to S. luridus. S. lineatus haplotypes formed a paraphyletic group with S. guttatus, and an early isolation of Maldives S. lineatus was suggested. Unexpectedly, S. randalli did not appear as the sister-species of S. vermiculatus, but its haplotypes instead were embedded within the West Pacific S. lineatus haplogroup, suggesting recent introgression. Among currently-recognized sister-species with parapatric distribution, S. doliatus and S. virgatus haplotypes formed a single, unresolved haplogroup, as did $S$. unimaculatus and $S$. vulpinus. The occurrence of two distinct clades within $S$. fuscescens was confirmed. 


\section{Introduction}

Increasingly complex theories are being developed regarding the origin and evolution of marine species in the central Indo-West Pacific region, whose coral reef and lagoon habitats harbour the highest biological diversity of all seas (Woodland, 1983; Palumbi, 1996; Hughes et al., 2002; Barber and Bellwood, 2005; Briggs, 2006). Molecular phylogenies provide the information against which hypotheses on the biogeography of species and scenarios of ecological specialization can be tested.

Rabbitfishes (Siganidae) are typical Indo-Pacific coral-reef fishes, that occupy all types of coastal habitats, from estuaries and mangroves to the reef front, the reef flat, and seaweed mats in the lagoon. Twenty eight nominal species are currently recognized in that family, based on morphology and colour patterns (Woodland, 1990; Randall and Kulbicki, 2005). Fishes of the family Siganidae exhibit uniformity in those characters (i.e. numbers of fin spines and rays, tooth shape, tooth count) which the systematics of fishes usually rely on. The fact that a majority of fishes of the family have bright and unique colour patterns has been exploited for defining species boundaries, but higher-level classification essentially relies on gross body proportions, shape of tail, and length of snout (Woodland, 1990). The family Siganidae in its present description consists of a single genus, Siganus, which has been subdivided into sub-genera Siganus and Lo, the latter to distinguish those five species that possess a prominent, tubular snout (De Beaufort and Chapman, 1951; Woodland, 1990; Randall, 2005). The other species have "pointed, blunt, or tumid snouts" (Woodland 1990). Lo was originally erected as a genus by Seale (1906), but Woodland (1990) considered that the differences in snout shape between Lo and Siganus were not sufficiently clear-cut for being recognized as different genera, arguing that the pointed shape of the snout of $S$. corallinus approaches the condition of $S$. (Lo) uspi, whose snout is the shortest of all 5 Lo species. Presumed, closely related (sibling) species of Siganidae have essentially parapatric distributions. Nine such groups of sibling taxa have been recognized (Woodland, 1999), most of which share their common boundaries in the central Indo-West Pacific region. It has been argued that this phenomenon may result from habitat specialization together with competitive exclusion, and be a cause of higher species richness in an area where the diversity of habitats is greater than in other regions of the Indo-Pacific (Woodland, 1983; 1999; Barber and Bellwood, 2005).

Only scarce genetic data are available concerning fishes of the family Siganidae. An allozyme study conducted on ten Siganus spp. species allowed phylogenetic inference based on allozyme distances (Lacson and Nelson, 1993). The authors provisionally concluded that a major dichotomy separated deep-bodied and shallow-bodied Siganus spp. They observed that the genetic distance between two sibling species with virtually parapatric distribution $(S$. randalli and $S$. vermiculatus) was of the same order as those estimated between geographic populations within a species (Fig. 1). Also, the subgenus Lo, represented by $S$. vulpinus, did not appear as a clade distinct from the other species. Instead, S. vulpinus paired with $S$. punctatus (Fig. 1), a result that was deemed "unpredicted" by Lacson and Nelson (1993). No test of robustness of the allozyme tree was, nor can be performed from the data that were 
then published, hence it is not clear how much reliable its topology was. These authors noticed that $S$. argenteus was the least divergent genetically from outgroup Naso lituratus (Acanthuridae), but the topology of the allozyme tree (Fig. 1) apparently contradicted this statement. Other, recent genetic surveys focused on the loss of genetic variation in S. luridus and S. rivulatus populations subsequent to their crossing of the Suez Canal (Bonhomme et al., 2003; Hassan et al., 2003; Azzurro et al., 2006), and on examining the barcoding potential of a short fragment of the cytochrome $b$ gene, that was also used to estimate the degree of genetic differentiation between populations of eight Siganidae species at the scale of the West Pacific (Lemer et al., 2007). Further phylogenetic analysis is necessary to understand the evolution of morphology (i.e. body proportions and snout shape) and life-history (i.e. duration of the pelagic stage) in Siganidae. As these characters are of obvious ecological relevance, they may have been involved in speciation in Siganidae.

Here, we inferred the phylogeny of twenty Siganus species from the nucleotide sequences of a 825-bp composite fragment of the mitochondrial DNA, with the following objectives: to test the validity of the current taxonomy of Siganidae, based on Woodland's (1990) extensive revision; to explore the patterns of lineage diversification in that family and eventually relate them to scenarios of ecological specialization; to address the genetic relationships between parapatrically distributed sibling species and to tentatively infer speciation processes.

\section{Materials and methods}

Siganidae species were separated by Woodland (1990) into "deep-bodied" and "fusiform" species. For the 20 species examined here, the range of variation of the ratio of standard length to body depth was the following: $S$. argenteus, 2.4-3.0; S. canaliculatus, 2.4-2.8; S. corallinus, 1.7-2.4; S. doliatus, 1.8-2.2; S. fuscescens, 2.3-2.9; S. gutattus, 1.8-2.3; S. javus, 2.0-2.3; S. lineatus, 1.9-2.2; S. luridus, 2.1-2.8; S. puellus, 2.3-2.6; S. punctatus, 1.9-2.3; S. randalli, 2.0-2.2; S. rivulatus, 2.6-3.2; S. spinus, 2.3-2.8; S. sutor, 2.2-2.6; S. unimaculatus, 2.1-2.4; S. vermiculatus, 1.92.2; S. virgatus, 1.8-2.3; S. vulpinus, 1.9-2.4; S. woodlandi, 2.1-2.4 [after Woodland (1990) except S. woodlandi: Randall and Kulbicki (2005)]. S. puellus tends to show a ratio of standard length to body depth higher than the other deep-bodied species, but nevertheless cannot be considered fusiform, owing to its rather flat, rectangular shape. Some of these species $(S$. fuscescens, S. luridus, S. rivulatus, S. spinus, S. sutor), all fusiform, have a drab colour while the other species exhibit bright colours and/or contrasted colour patterns (Woodland, 1990). Most species of the reef front, all brightly coloured, are encountered as pairs (S. corallinus, $S$. doliatus, S. puellus, S. punctatus, S. vulpinus) while the other species usually occur as small schools (Randall et al., 1990; Woodland, 1990; Woodland, 2001). Randall and Kulbicki (2005) report that $S$. woodlandi occurs in schools as does $S$. argenteus, partly based on a picture of a school of $S$. woodlandi by Fourmanoir and Laboute (1976). However, one of us (P. B.) has regularly observed pairs of adult $S$. woodlandi on various parts of the reef front around southern New Caledonia at 6-15 m depth. In only one instance did three pairs of $S$. woodlandi appear to forage together, forming an ephemeral, loose school of 6 individuals. S. argenteus is the only Siganidae known to spawn pelagic eggs and to possess an extended pelagic, 
prejuvenile stage that is analogous to the acronurus stage of Acanthuridae (which also have pelagic eggs) (Woodland, 1990; Leis and Carson-Ewart, 2001). All other Siganidae species except, perhaps, $S$. woodlandi for which no life-history data are available, spawn benthic eggs (Popper et al., 1979; Leis and Richards, 1984) or are believed to (Woodland, 1990), and lack a transitional pelagic stage (Woodland, 1990; Leis and Carson-Ewart, 2001). Four pairs of sibling, parapatric species sensu Woodland (1999) were sampled for the present survey. These were $S$. doliatus / S. virgatus, S. guttatus / S. lineatus, S. luridus / S. spinus and S. unimaculatus / S. vulpinus.

Details on the individuals sampled (sampling location and date, voucher specimens) are in Table 1. DNA was extracted from ethanol-preserved fin clips or muscle fragments using either the standard phenol-chloroform extractions with Phase-Lock GelTM tubes (Eppendorf, Le Pecq, France), or the DNeasy ${ }^{\circledR}$ kit (Qiagen GmbH, Hilden, Germany). Individual DNA extracts were subjected to PCR amplification of two partial mitochondrial genes: a 326-bp fragment of the cytochrome $b$ gene, using a pair of degenerate primers (forward: 5'-TCMGAYATCGCCACAGCCTTCTC-3'; reverse: 5'AGGAAGTGGAAKGCGAAGAA-3') designed from the alignment of the cytochrome $b$ gene sequences of Siganidae available in GENBANK (accession nos. AY190542-AY190555), and an expected 575-bp fragment of the 16s rRNA gene, using the forward and reverse primers (respectively, 5'-CGCCTGTTTATCAAAAACAT-3' and 5'CCGGTCTGAACTCAGATCACGT-3') of Clements et al. (2003). The amplification reactions were done in 96-well plates with each well containing $20 \mu \mathrm{L}$ reaction mixture $[2 \mu \mathrm{L}$ template DNA, $2.5 \mathrm{mM} \mathrm{MgCl}, 0.48 \mathrm{~m} M$ dNTP mix, $0.5 \mu M$ of each primer and $0.5 \mathrm{U}$ Taq polymerase (Promega, Madison WI, U.S.A.)] in a Robocycler ${ }^{\mathrm{TM}}$ thermocycler (Stratagene, La Jolla CA, U.S.A.). The PCR program consisted of 3 min DNA-denaturation (at $94^{\circ} \mathrm{C}$ ) followed by 35 cycles of 1 min denaturation $\left(94^{\circ} \mathrm{C}\right) / 1$ min annealing $\left(60^{\circ} \mathrm{C}\right) / 1 \mathrm{~min}$ elongation $\left(72^{\circ} \mathrm{C}\right)$. The PCR products were shipped to GATC Biotech (Konstanz, Germany), or Macrogen (Seoul, South Korea) for nucleotide sequencing and the sequences were subsequently retrieved from the company's Internet website. Nucleotide sequences were deposited in GENBANK (list in Table 1).

All nucleotide sequences were aligned using BIOEDIT (Hall, 1999). The phylogenetic relationships among species in the genus Siganus were inferred from the matrix combining cytochrome $b$ and $16 \mathrm{~S}$ rDNA sequence data using three different algorithms: neighbourjoining (NJ) (Saitou and Nei, 1987), maximum parsimony (MP) (Fitch, 1971), and maximum likelihood (ML) (Felsenstein, 1973). NJ and MP analyses were done using MEGA 3.1 (Kumar et al., 2004). Gaps were treated as deletions in pairwise comparisons of sequences (option "Pairwise-Deletion" in Mega 3.1). ML analysis was done using PhyML (Guindon and Gascuel, 2003). Three substitution models were considered for analysing the nucleotide differences between haplotypes: Jukes-Cantor (Jukes and Cantor, 1969), Kimura-2 parameter (Kimura, 1980), and Tamura-Nei (Tamura and Nei, 1993). The substitution model for NJ and $\mathrm{ML}$ analyses was chosen according to the likelihood approach implemented in 
MODELTEST (Posada and Crandall, 1998), version 3.7 (2006); the best fit was provided by a Tamura-Nei model with $\Gamma$-distributed rates of substitution per site $(\alpha=0.5)$.

\section{Results}

Mitochondrial-DNA sequence data were obtained on a total of 825 base pairs (bp) contributed by a fragment of the cytochrome $b$ gene $(300 \mathrm{bp})$ and a fragment of the $16 \mathrm{~S}$ rRNA gene (521-522 bp before alignment), for 164 individuals of 20 Siganidae and three Acanthuridae species (GENBANK accession nos. listed in Table 1). For the cytochrome $b$ gene fragment, 115 nucleotide sites were variable across the whole dataset (19 first positions, 3 second positions, 93 third positions) resulting in 12 amino-acid substitutions. All 16S rDNA data were easily aligned with 6 single-nucleotide gaps, yielding 87 variable nucleotide sites. The NJ tree obtained from the matrix of pairwise nucleotide distances is presented in Fig. 2. MP analysis of the combined dataset yielded a set of 64 most parsimonious trees of 550 steps, whose topology at the supra-specific level was nearly identical to that of the NJ tree, as was that of the tree produced by ML analysis. The only differences concerned the position of the branch leading to $S$. javus relative to that leading to $S$. puellus, which was poorly resolved in NJ and unresolved with MP and ML analysis, and the position of the node separating $S$. vermiculatus from the $S$. guttatus / S. lineatus haplogroup. Percentages of occurrence of a node after bootstrap resampling are given for each NJ, MP, and ML analysis (Fig. 2).

The inner tree topology was characterized by three well-supported and deeply separated ingroup clades of similar lengths (I-III on Fig. 2). Clade I grouped all deep-bodied species, while Clade III grouped all species with fusiform body except $S$. argenteus. S. argenteus and $S$. woodlandi (whose ratio of standard length to body depth is intermediate between those of deep-bodied and fusiform species) formed Clade II. All species that live in pairs on the reef front, except $S$. woodlandi, were grouped in Clade $I$, but the latter also included species that live in small schools or pairs in turbid habitats such as mangroves, estuarine lakes and estuaries (S. guttatus, S. javus, S. lineatus, S. vermiculatus). All drab-coloured species, which also have tumid snout and form large schools, were grouped into Clade III.

S. luridus and S. spinus appeared to have diverged relatively early from each other (average nucleotide divergence estimate between haplotypes of the two species, $\wedge d=0.068$ ) and did not appear as sister-clades (Fig. 2). S. rivulatus and S. sutor appeared to be sister-clades (with $\wedge d=0.020)$. S. lineatus haplotypes formed a paraphyletic cluster with $S$. guttatus. The paraphyly of $S$. lineatus haplotypes was caused by the external placement of the Maldives $S$. lineatus haplotype relative to the group formed by $S$. guttatus and those $S$. lineatus haplotypes that were sampled in Sulawesi and New Caledonia (i.e., across the West Pacific) (Fig. 2). $S$. guttatus and West Pacific $S$. lineatus appeared as very recently differentiated sister-clades $(\wedge d=$ 0.005). S. randalli haplotypes were embedded within the West Pacific S. lineatus haplogroup. S. doliatus haplotypes similarly formed a single, common haplogroup with S. virgatus, and so did S. unimaculatus with S. vulpinus. S. fuscescens haplotypes clustered into two distinct, although closely related haplogroups $(\wedge d=0.009)$. 


\section{Discussion}

The present results distinguished three major clades in Siganidae, which had not been identified earlier (Lacson and Nelson, 1993; Lemer et al., 2007). The early separation between deep-bodied and fusiform species indicates that general body shape has a strong phylogenetic component in Siganidae. This separation however was not complete, as Clade II grouped both a fusiform species ( $S$. argenteus) and a species with intermediate body depth $(S$. woodlandi). Nevertheless, the caudal fin in the two latter species is strongly forked, unlike in all the other Siganidae species. General body shape thus underwent early diversification in Siganidae and has since then been relatively stable. A similar situation has been described in emperor fishes, Lethrinus spp. (Lethrinidae) (Lo Galbo et al., 2003). This situation is not systematic among Teleosteans, where body proportions may also change rapidly, like in e.g. Naso spp. (Acanthuridae) (Klanten et al., 2004) and Cichlidae (Kassam et al., 2006). The distinction of two basic morphological types in Siganidae is clearly correlated with distinct life-styles. A proportion of the deep-bodied species occur in pairs close to the hard-coral substratum on the reef front, where they can sneak into crevices for feeding and for seeking protection from predators. This in turn favours territoriality and, perhaps, pairing behaviour. Fusiform species conversely occur on reef flats and algal flats and rely on schooling behaviour and swimming speed for escaping predators. Correlatively, the colour of the fusiform species is drab (an advantage in open habitats also frequented by predators), while that of the species of the reef front is usually bright and contrasted (e.g. Woodland, 1990; Randall, 2005).

S. argenteus [also a schooling, fusiform species; Woodland (1990)] was placed together with $S$. woodlandi in a distinct clade that appeared to coalesce simultaneously with the two others. This early trichotomy may reflect the true phylogeny, or conceal two successive dichotomies that the present sequence data were not sufficient to resolve. Given that $S$. argenteus possesses the prejuvenile, pelagic stage that is also present in Acanthuridae, parsimonious reasoning leads to considering the prejuvenile stage as ancestral in Siganidae, in which case the prejuvenile stage would have been lost once, or twice (depending on whether the actual basic divergence was a succession of two dichotomies, or a trichotomy), early in the history of the family. Life-history data for $S$. woodlandi, which are presently lacking, are desirable for a better understanding of the evolution of the prejuvenile stage in Siganidae.

The present results do not support the phylogenetic separation of Siganidae species with tubular snout, heretofore grouped under subgenus Lo (Seale, 1906), versus the other species (subgenus Siganus), thus confirming Lacson and Nelson's (1993) preliminary conclusions from allozymes. S. (Lo) unimaculatus and $S$. (Lo) vulpinus branched within a subclade of Clade $I$, as sister-species to $S$. puellus and $S$. punctatus, both with slightly elongate snout and placed under subgenus Siganus. We hypothesize that the mechanism for the apparition of the tubular snout of $S$. unimaculatus, S. vulpinus and related species (namely, S. magnificus, S. niger and $S$. $u s p i$ is ecological specialization, as a longer snout allows easier access to pockets of algae growing at the dead basis of hard-coral colonies (Woodland, 1990). Albeit moderate 
compared to S. unimaculatus and S. vulpinus, an elongate snout independently evolved in $S$. corallinus (Fig. 2), which is another deep-bodied species typical of the coral-reef front habitat. Therefore, the elongate / tubular snout appears to be a specialized state that arose in deepbodied species dwelling on the coral reef.

Quoting Woodland (1990), "S. sutor is very similar in proportions to S. canaliculatus and S. fuscescens", but only "field observations of the colours of live fish indicate that it is distinct". According to the present results, S. sutor actually appears as the sister-species of $S$. rivulatus. Those two species form a subclade within a strongly supported monophyletic group that also comprises $S$. canaliculatus and $S$. fuscescens. Both S. canaliculatus and $S$. fuscescens have an IndoPacific distribution, but both are geographically isolated from S. sutor and S. rivulatus (Woodland, 1990). S. sutor is endemic to the western Indian Ocean while until recently the distribution of S. rivulatus was confined to the Red Sea (Woodland, 1990). Therefore, it is sensible to assume that the two latter species arose by allopatric speciation, and that they are an offshoot of an ancestral S. canaliculatus / S. fuscescens form from which their ancestor was geographically isolated.

We examined another pair of presumed sibling species within Clade III, namely $S$. luridus / S. spinus. Woodland's (1990; 1999) rationale for placing S. luridus and S. spinus as sibling species was their similar ratio of total length to body depth, the similar size and stoutness of their fin spines, and their parapatric distribution. The topology of the mitochondrial tree (present results) however does not support the sibling-species hypothesis. The genetic divergence patterns reported here and above thus highlighted the limitations of general morphology for accurately assessing evolutionary relationships at the immediate supraspecific level, at least in fusiform, drab species.

Among the other currently-recognized sister-species with parapatric distribution, $S$. doliatus and $S$. virgatus haplotypes formed a single, unresolved haplogroup, as $\operatorname{did} S$. unimaculatus and $S$. vulpinus. Since $S$. doliatus and $S$. virgatus are believed to hybridize in their zone of contact in the Indo-Malay region (Woodland, 1990; Randall, 2005), it is possible that the latter harbours $S$. doliatus mitochondria as a result of introgression. In that case, further sampling of $S$. virgatus would be necessary, ideally outside the zone of overlap to sample 'true' S. virgatus mitochondria. Alternatively, the divergence between the two species may be recent, to the point that the sorting of their mitochondrial lineages is still not perceptible. The same rationale applies to the pair S. unimaculatus / S. vulpinus.

In cases where several haplotypes were sampled in a species, they clustered as distinct haplogroups and intraspecific nucleotide distances were at least about one order of magnitude lower than the distances separating two nominal species, thus validating Woodland's (1990) taxonomy at the species level. Apart from the two pairs of sibling species discussed in the above paragraph, there was one noticeable exception to this general pattern, which concerned the ensemble formed by $S$. lineatus, $S$. guttatus and $S$. randalli haplotypes. Although restricted to a single haplotype, the Maldives sample of $S$. lineatus appears as clearly distinct from all five other S. lineatus haplotypes, sampled across the West Pacific. Moreover, the Maldives S. lineatus haplotype branches externally to the clade formed by $S$. guttatus and 
West-Pacific S. lineatus. Considering both the geographic distribution and the patterns of genetic differentiation observed in the $S$. guttatus / S. lineatus species complex, a two-step scenario of genetic differentiation may be proposed, with a first event of allopatric differentiation separating a Maldives population from a stock ancestral to both $S$. guttatus and West-Pacific $S$. lineatus and a subsequent, second event of allopatric differentiation between the two latter. S. guttatus and West Pacific S. lineatus subsequently underwent secondary contact in the Indo-Malay region. Both the pattern of reciprocal monophyly here observed between the two latter entities and the maintaining of two distinct ornamentation types (spotted: S. guttatus; lineate: S. lineatus) on either side of a narrow zone of contact in the IndoMalay archipelago (Woodland 1990) despite possible hybridization (Lemer et al., 2007) confirm they have reached the status of biological species. The present results, if confirmed by a larger sample of haplotypes, therefore may challenge the current placement of Maldives $S$. lineatus as conspecific with West Pacific $S$. lineatus. Alternatively, the paraphyly of $S$. lineatus may be only apparent, with West-Pacific $S$. lineatus having been recently introgressed by $S$. guttatus mitochondria while the genomic integrity of Maldives S. lineatus was preserved because of its geographical isolation. An indirect way of addressing that question is now to study the population genetics of the $S$. guttatus / S. lineatus contact zone, using nuclear-DNA markers.

Both morphology and colour patterns (Woodland, 1990), and allozymes (Lacson and Nelson, 1993; Fig. 1) indicate a close relationship of $S$. randalli with $S$. vermiculatus.

Unexpectedly, $S$. randalli haplotypes did not form a sister-clade to those of $S$. vermiculatus, but instead were embedded within the West-Pacific S. lineatus haplogroup, suggesting recent introgression of $S$. randalli by $S$. lineatus mitochondria. Although the allozyme study of Lacson and Nelson (1993) unfortunately did not include S. lineatus samples, the genetic distance between its close relative $S$. gutattus and $S$. vermiculatus was nearly one order of magnitude larger than the distance between $S$. randalli and $S$. vermiculatus.

Another point deserving further attention is the confirmation of two distinct subclades within S. fuscescens. This was earlier hinted by Lemer et al. (2007), based on a much shorter mtDNA fragment and on smaller sample sizes. Here, one subclade appeared to be geographically widely distributed, from the Riau archipelago to New Caledonia, while despite substantial sampling effort the other subclade seemed to be restricted to the South-West Pacific, with haplotypes sampled exclusively in the Solomon Islands and New Caledonia. This phylogeographic pattern may correspond to a former history of allopatric differentiation followed by secondary contact, or, perhaps, to introgression from a yet undescribed, cryptic species within the current taxon $S$. fuscescens. Our suspicion that $S$. fuscescens might consist of two reproductively isolated forms is reinforced by Woodland's (1999) sibylline notice that "further study since the publication of [his 1990] revision suggests that cryptic species may need to be dissected out of Siganus fuscescens". The use of nuclear markers [e.g. lengthpolymorphic introns; Hassan et al. (2002)] to test the null hypothesis of panmixia in populations harbouring the two mitochondrial types is warranted. 


\section{Acknowledgements}

Funded by IRD-UR 128, Dimar, ZoNéCo, and Fonds Pacifique pour le développement (French Government). The following people contributed fish specimens or tissue samples: R.C. Anderson, P. Boblin, L. Carassou, A. Collet, E. Hardman, M. Hassan, J.-L. Justine, J. Kwik, D. Lecchini, M. Leopold, the Li-Khau family, M. Low, C. Mellin, G. Mou Tham, D. Neo, J.E. Randall, E. Tardy, E. Tessier, L. Vigliola, and P. Villard. C. Rocher offered technical assistance at the early stages of this work. Helpful comments on earlier versions of this manuscript were made by J.-D. Durand, J.E. Randall, and two anonymous reviewers. The hypothesis of a distinct Maldives $S$. lineatus population was first pointed out by R.C. Anderson and J.E. Randall in e-mails to P.B.

\section{References}

Azzurro, E., Golani, D., Bucciarelli, G., Bernardi, G. 2006. Genetics of the early stages of invasion of the Lessepsian rabbitfish Siganus luridus. J. Exp. Mar. Biol. Ecol. 333, 190-201.

Barber, P.H., Bellwood, D.R., 2005. Biodiversity hotspots: evolutionary origins of biodiversity in wrasses (Halichoeres: Labridae) in the Indo-Pacific and new world tropics. Mol. Phyl. Evol. 35, 235-253.

Bonhomme, F., Baranes, A., Golani, D., Harmelin-Vivien, M., 2003. Lack of mitochondrial differentiation between Red Sea and Mediterranean populations of the Lessepsian rabbitfish, Siganus rivulatus (Perciformes: Siganidae). Sci. Mar. 67, 215-217.

Briggs, J.C., 2006. Proximate sources of marine biodiversity. J. Biogeogr. 33, 1-10.

Clements, K.D., Gray, R.D., Choat, H.J., 2003. Rapid evolutionary divergences in reef fishes of the family Acanthuridae (Perciformes: Teleostei). Mol. Phyl. Evol. 26, 190-201.

De Beaufort, L.F., Chapman, W.M., 1951. The fishes of the Indo-Australian archipelago. Brill, Leiden, 484 pp.

Felsenstein, J., 1973. Maximum likelihood and minimum-steps methods for estimating evolutionary trees from data on discrete characters. Syst. Zool. 22, 240-249.

Fitch, W.M., 1971. Towards defining the course of evolution: minimum change for a specific tree topology. Syst. Zool. 20, 406-416.

Fourmanoir, P., Laboute, P., 1976. Poissons de Nouvelle-Calédonie et des NouvellesHébrides. Editions du Pacifique, Papeete, 376 pp.

Guindon, S, Gascuel, O., 2003. A simple, fast and accurate algorithm to estimate large phylogenies by maximum likelihood. Syst. Biol. 52, 696-704.

Hall, T.A., 1999. BIOEDIT: a user friendly biological sequence alignment editor and analysis program for windows 95/98/NT. Nucl. Acids Symp. Ser. 41, 95-98.

Hassan, M., Harmelin-Vivien, M., Bonhomme, F., 2003. Lessepsian invasion without bottleneck: example of two rabbitfish species (Siganus rivulatus and Siganus luridus). J. Exp. Mar. Biol. Ecol. 291, 219-232.

Hassan, M., Lemaire, C., Fauvelot, C., Bonhomme, F., 2002. Seventeen new exon-primed intron-crossing polymerase chain reaction amplifiable introns in fish. Mol. Ecol. Notes 2, 334-340. 
Hughes, T.P., Bellwood, D.R., Connolly, S.R., 2002. Biodiversity hotspots, centres of endemicity, and the conservation of coral reefs. Ecol. Lett. 5, 775-784.

Jukes, T.H., Cantor, C.R., 1969. Evolution of protein molecules. In: Munro, H.N. (Ed.), Mammalian protein metabolism. Academic Pres, New York, pp. 21-132.

Kassam, D., Seki, S., Horic, M., Yamaoka, K., 2006. Nuclear markers reveal that inter-lake cichlids' similar morphologies do not reflect similar genealogy. Mol. Phyl. Evol. 40, 383388.

Kimura, M., 1980. A simple method for estimating evolutionary rate of base substitutions through comparative studies of nucleotide sequences. J. Mol. Evol. 16, 111-120.

Klanten, S.O., van Herwerden, L., Choat, H.J., Blair, D., 2004. Patterns of lineage diversification in the genus Naso (Acanthuridae). Mol. Phyl. Evol. 32, 221-235.

Kumar, S., Tamura, K., Nei, M., 2004. MEgA3: Integrated software for molecular evolutionary genetics analysis and sequence alignment. Brief. Bioinformatics 5, 150-163.

Lacson, J.M., Nelson, S.G., 1993. Genetic distances among fishes of the genus Siganus (Siganidae) from the western Pacific ocean. Mar. Biol. 116, 187-192.

Leis, J.M., Carson-Ewart, B.M., 2001. The larvae of Indo-Pacific coastal fishes: an identification guide to marine fish larvae. Brill, Leiden, $850 \mathrm{pp}$.

Leis, J.M., Richards, W.J., 1984. Acanthuroidei : development and relationships. In: Moser, H.G., Richards W.J., Cohen D.M., Fahay, M.P., Kendall, A.W, Richardson, S.L. (Eds.), Ontogeny and systematics of fishes. Am. Soc. Ichthyol. Herpetol. Spec. Publ. 1, 547-551.

Lemer, S., Aurelle, D., Vigliola, L., Durand, J.-D., Borsa, P., 2007. Cytochrome $b$ barcoding, molecular systematics, and geographic differentiation in rabbitfishes (Siganidae). C. R. Biol. 330

Lo Galbo, A.M., Carpenter, K.E, Reed, D.L., 2002. Evolution of trophic types in emperor Fishes (Lethrinus, Lethrinidae, Percoidei) based on cytochrome $b$ gene sequence variation. J. Mol. Evol. 54, 754-762.

Palumbi, S.R., 1996. What can molecular genetics contribute to marine biogeography? An urchin's tale. J. Exp. Mar. Biol. Ecol. 203, 75-92.

Popper, D., Pitt, R., Zohar, Y. 1979. Experiments on the propagation of Red Sea siganids and some notes on their reproduction in nature. Aquaculture 16,177-181.

Posada, D., Crandall, K.A., 1998. MODELTEST: testing the model of DNA substitution. Bioinformatics 14, 817-818.

Randall, J.E., 2005. Reef and shore fishes of the South Pacific. University of Hawai'i Press, Honolulu, 707 pp.

Randall, J.E., Allen, G.R., Steene, R.C., 1990. Fishes of the Great Barrier Reef and Coral Sea. Crawford House, Bathurst, 506 pp.

Randall, J.E., Kulbicki, M., 2005. Siganus woodlandi, new species of rabbitfish (Siganidae) from New Caledonia. Cybium 29, 185-189.

Saitou, N., Nei, M., 1987. The neighbor-joining method: a new method for reconstructing phylogenetic trees. Mol. Biol. Evol. 4, 406-425.

Seale, A., 1906. Fishes of the south Pacific. Occ. Pap. B. P. Bishop Mus., Honolulu 4, 1-89. 
Tamura, K., Nei, M., 1993. Estimation of the number of nucleotide substitutions in the control region of mitochondrial DNA in humans and chimpanzees. Mol. Biol. Evol. 10, 512-526.

Tang, K.L., Berendzen, P.B., Wiley, E.O., Johnsson, G.D., Winterbottom, R., Morrissey, J.F., 1999. The phylogenetic relationships of the suborder Acanthuroidei (Teleostei: Perciformes) based on molecular and morphological evidence. Mol. Phyl. Evol. 11, 415425.

Woodland, D.J., 1983. Zoogeography of the Siganidae : an interpretation of distribution and richness patterns. Bull. Mar. Sci. 33, 713-717.

Woodland, D.J., 1990. Revision of the fish family Siganidae with description of two new species and comments on distribution and biology. Indo Pac. Fishes, B. Pauahi Bishop Mus., Honolulu 19, 1-136.

Woodland, D.J., 1999. An examination of the effect of ecological factors, especially competitive exclusion, on the distributions of species of an inshore, tropical, marine family of Indo-Pacific fishes (Siganidae). In: Séret, B., Sire, J.-Y. (Eds.), Proc. $5^{\text {th }}$ IndoPac. Fish Conf., Nouméa, 1997. Soc. Fr. Ichtyol., Paris, pp. 553-562.

Woodland, D.J., 2001. Siganidae, Rabbitfishes (spinefoots). In: Carpenter, K.E., Niem V. (Eds.), FAO species identification guide for fishery purposes, The living marine resources of the Western Central Pacific, Vol. 6, Bony fishes part 4 (Labridae to Latimeriidae), estuarine crocodiles. FAO, Rome, pp. 3627-3650. 
Table 1

Samples of Acanthuridae and Siganidae analysed for the present survey. IRDN : Institut de recherche pour le développement, Nouméa; MNHN: Museum national d'histoire naturelle, Paris; BPBM: Bernice Pauahi Bishop museum, Honolulu. 


\begin{tabular}{|c|c|c|c|c|}
\hline \multirow{2}{*}{$\begin{array}{l}\text { Species, } \\
\text { Sampling location }\end{array}$} & \multirow[t]{2}{*}{ Sampling date } & \multirow[t]{2}{*}{ Voucher specimens } & \multicolumn{2}{|c|}{ GENBANK accession nos. } \\
\hline & & & Cytochrome b & $16 S r R N A$ \\
\hline
\end{tabular}

ACANTHURIDAE

Acanthurus blochii

Southern lagoon, New Caledonia Apr. 2006

IRDN Ablo1, 2a

MNHN 2007-0003

Jul. 2006

Moruroa, Gambier archipelago

Naso unicornis

Southern lagoon, New Caledonia Nov. 2006

SIGANIDAE

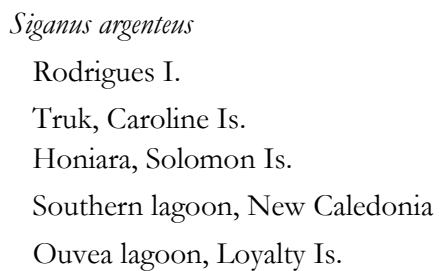

\section{S. canaliculatus}

Riau archipelago

Honiara, Solomon Is.

S. corallinus

Manus I., Bismarck archipelago

Honiara, Solomon Is.

Southern lagoon, New Caledonia

S. doliatus

Truk, Caroline Is.

Southern lagoon, New Caledonia

\section{S. fuscescens}

Riau archipelago

Misima I., Louisiades archipelago

Honiara, Solomon Is.

Southern lagoon, New Caledonia

S. guttatus

Makassar, Sulawesi I.

Aug. 2006

Apr. 2006

Aug. 2006

Feb. 2005-Mar. 2006

Feb. 2006

Nov. 2006

Aug. 2006

Aug. 2006

Aug. 2006

Feb.-July 2005

Apr. 2006

Feb. 2005-Apr. 2006

Nov. 2006

Nov. 2006

Aug. 2006

June 2005-Feb. 2006

Sep. 2005

Sep. 2005

Makassar, Sulawesi I.

S. lineatus

Addu atoll, Maldives archipelago

Makassar, Sulawesi I.

Honiara, Solomon Is.

New Caledonia

S. luridus

Lattaqiah, Syria

Reunion I.

S. puellus

Southern lagoon, New Caledonia

Truk, Caroline Is.
Aug. 2005

Sep. 2005

Aug. 2006

Apr. 2002-Mar. 2006

2002

May. 2006

Feb.-July 2005

Apr. 2006
MNHN 2007-0005

DQ898027

DQ898095, 096

EF210172

EF210160

EF210173

EF210162

$\begin{array}{ll}\text { DQ898028; } & \text { DQ898097; } \\ \text { EF210174 } & \text { EF210163 } \\ \text { DQ898035 } & \text { DQ898097 } \\ \text { DQ898030, 031 } & \text { DQ898097 } \\ \text { DQ898028, 030, 035, } & \text { DQ898097 } \\ \text { 036 } & \text { DQ898098 }\end{array}$

EF210175

EF210164

EF210176

EF210165

DQ898037

DQ898037,

EF210177

DQ898105

DQ898105

DQ898105

MNHN 2006-1526; MNHN 2007-0006 DQ898037

DQ898106

IRDN Sdol 2-4 a; MNHN 2006-1527; MNHN 2007-0007, 0008

\section{DQ898038}

DQ898106, 107

DQ898038, 039

\author{
IRDN Scff 2-5 a; MNHN 2007-0009 \\ MNHN 2006-1528, 1529, 1530
}

IRDN Slin 0, $2^{a} ;$ MNHN 2006-1531

EF210179-181
EF210182-184
DQ898040-042,
EF210178
DQ898040-045

DQ898047, 049, 050 DQ898108

DQ898052-054

DQ898109

DQ898062

DQ898108

DQ898055,059-061 DQ898108

DQ898059 DQ898108

DQ898055, 059-061 DQ898108

DQ898056-058

EF210185, 186

DQ898110, 111

DQ898110

DQ898063

DQ898112

DQ898063
DQ898112 
Southern lagoon, New Caledonia

Makassar, Sulawesi I.

Truk, Caroline Is.

S. randalli

Honiara, Solomon Is.

Manus I., Bismarck archipelago

S. rivulatus

Lattaqiah, Syria

2002

Aug. 2006

Aug. 2006

Aug. 2006

Jan. 2003; June 2005

Apr. 2006

Aug. 2006

Nov. 2006

Makassar, Sulawesi I

Sep. 2005

Nov. 2006

Makassar, Sulawesi I.

S. vulpinus

Southern lagoon, New Caledonia

Truk, Caroline Is.

Feb.-July 2005

Apr. 2006

S. woodlandi

Southern lagoon, New Caledonia
MNHN 2006-1534

MNHN 2006-1535

MNHN 2007-0011, 0012

DQ898084, 085

DQ898083

DQ898118

DQ898039

EF210171

IRDN Spun 2-4 a; MNHN 2006-1533;

DQ898068, 069

DQ898113, 114

DQ898068

DQ898113

DQ898113

DQ898059

EF210188

DQ898108

DQ898108

DQ898075-078

DQ898115, 116

(20)

DQ898079

DQ898117

DQ898117

EF210193, 194

DQ898115

Q898119; EF210170

IRDN JNC1782; MNHN 2006-1536

DQ898084

DQ898119

DQ898084

DQ898119

${ }^{a}$ skulls 
Captions to figures

Fig. 1. Siganus spp. Neighbour-joining tree [MEGA 3.1: Kumar et al. (2004)] built from pairwise Rogers' genetic distances estimated from allelomorph frequencies at 14 enzyme loci [Table 2 of Lacson and Nelson (1993)]. Naso lituratus (Acanthuridae) chosen as outgroup [see Tang et al. (1999) for a justification]. Scale bar: 10\% Rogers' genetic distance.

Fig. 2. Siganus spp haplotypes (Acanthurus blochii, A. triostegus and Naso unicornis haplotypes as outgroup). Neighbour-joining (NJ) phylogeny obtained from the combined nucleotide sequence data set of cytochrome $b(300 \mathrm{bp})$ and 16s rRNA (525 bp) gene fragments. Nucleotide distances estimated according to a Tamura-Nei model with $\Gamma$-distributed rates of substitution [MEGA 3.1: Kumar et al. (2004)]. Bootstrap resampling scores $>50 \%$ given as \% left to a node [bold: NJ, 1000 resamplings; italics: maximum parsimony (MEGA 3.1), 1000 resamplings; regular: maximum likelihood (PHYML: Guindon and Gascuel [2003]), 100 resamplings]. Geographic origin of samples: Syria $(\mathbf{X})$; Mascarene archipelago (+); Addu atoll, Maldives ( $\square)$; Riau archipelago $(\Delta)$; Sulu Sea

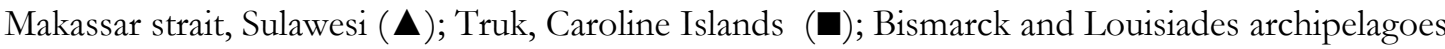
$(\bullet)$; Solomon Islands $(\bullet)$; New Caledonia $(\bullet)$; Ouvéa, Loyalty Islands (O); Moorea, Society Islands $(\nabla)$. Behaviour: S, schooling; P, pairing; (references in section 2.). Scale bar: $2 \%$ nucleotide distance. 


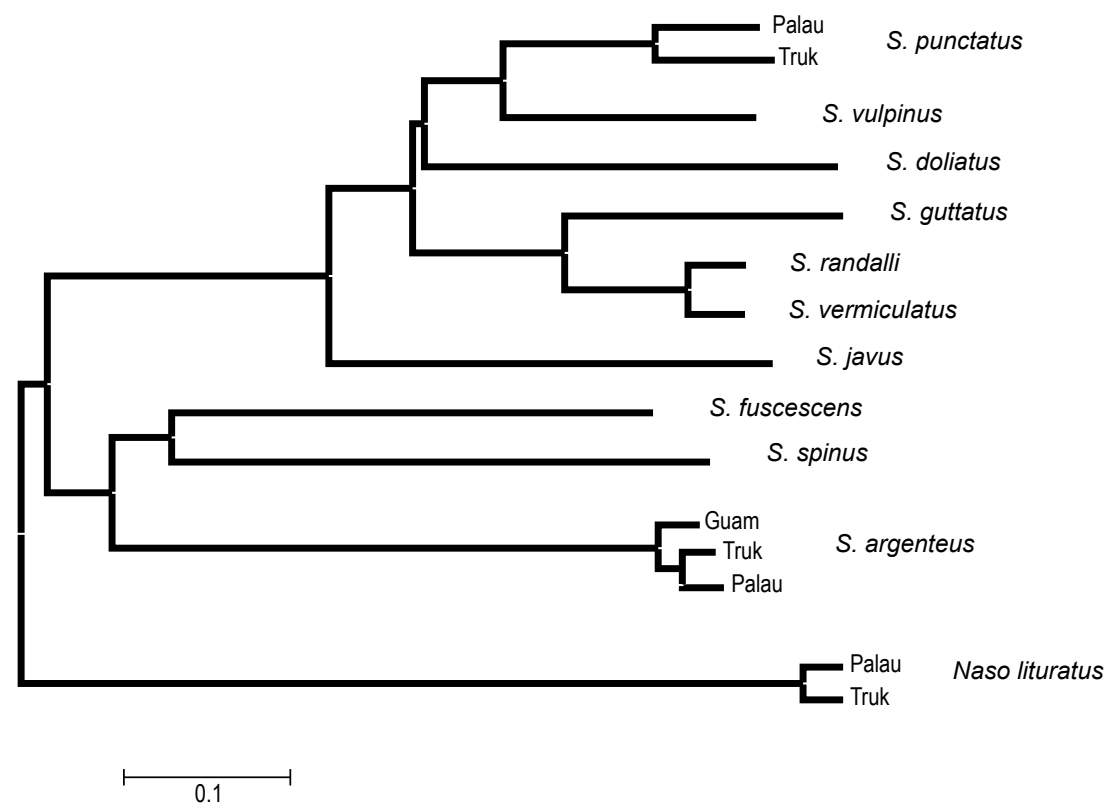




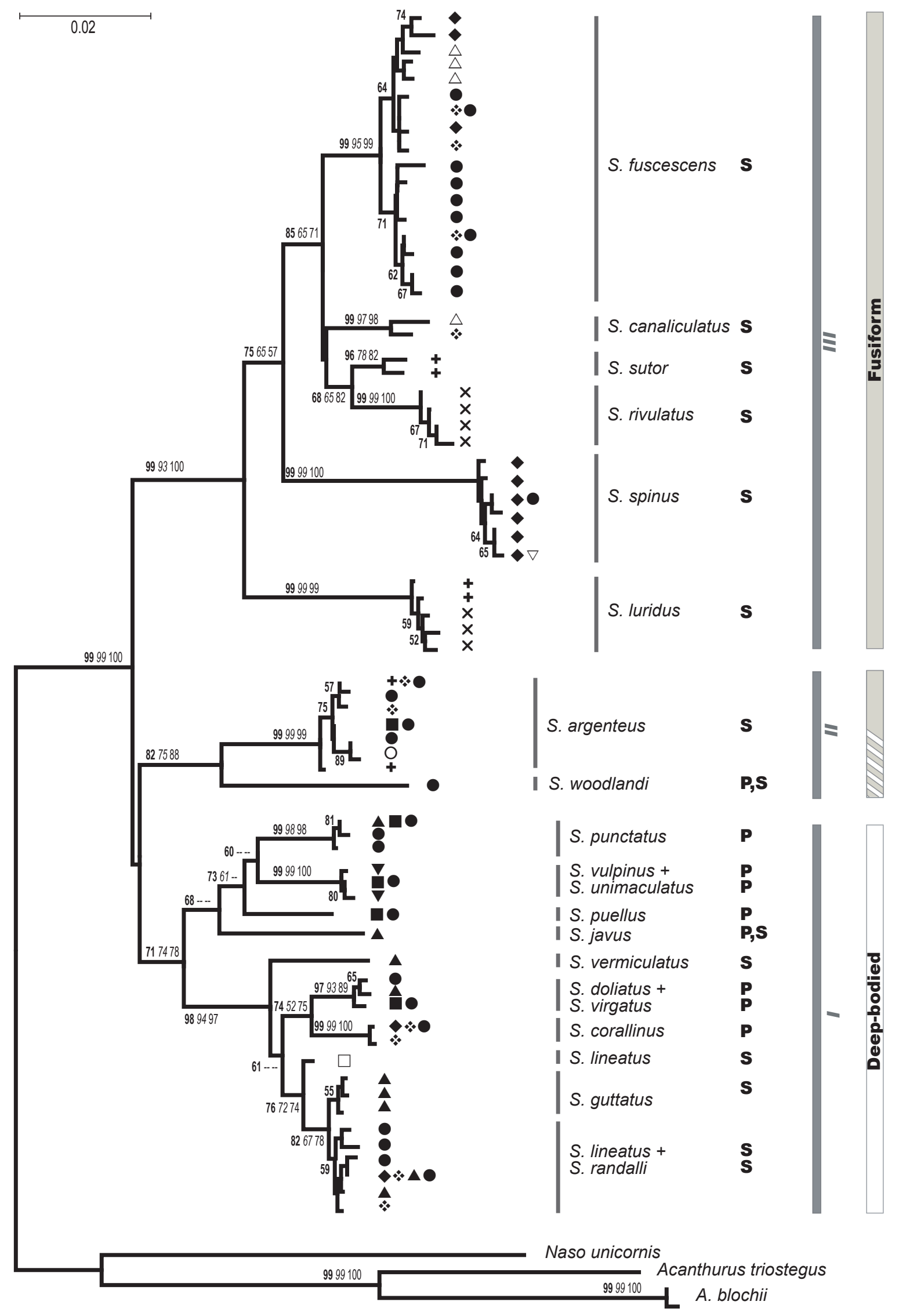

